\title{
Subjective Inequality: a Review of International Comparative Studies on People's Views about Inequality
}

\begin{abstract}
This study reviews international comparative studies investigating people's views on inequality. These studies are classified using a framework consisting of three types of conceptions of inequality and two dimensions of inequality. Four perspectives are discussed explaining cross-national differences in views on inequality: the modernist, the culturalist, the micro and the macro perspective. The findings of studies comparing views on inequalities in post-communist and Western states provide more support for the modernist than for the culturalist perspective. Few comparative studies appear to investigate views on inequalities as independent variables impacting on other social attitudes and behaviours. It is argued that the social relevance of the field will be enhanced if more studies can show that views on inequality have an effect on social outcomes complementary to that of objective inequalities.
\end{abstract}

Keywords: Perception of inequalities; Social justice; International comparison; Modernist perspective; Welfare regimes.

I N T H E L A S T T H R E E D E C A D E S the number of international comparative studies investigating people's views on inequality has steadily risen. This expansion was greatly facilitated by the proliferation of international public opinion surveys, such as the International Social Survey Programme (ISSP), the International Social Justice Project (ISJP) and the European Values Study/World Values Survey (Evs/wvs). Yet, as both the possibilities of studying attitudes on inequality and the number of such studies have increased, it has become ever more challenging to obtain a clear picture of the state of the art of the research in the field. A problem complicating a compilation of research findings is that views on inequality constitute a multidimensional phenomenon, as one quickly discovers when reviewing a number of comparative studies. Such views can be said to involve three types of conceptions-perceptions of existing

Jan Germen Janmaat, Department of Lifelong and Comparative Education, Institute of Education, London [G.Janmaat@ioe.ac.uk].

European Fournal of Sociology, LIV, 3 (2013), pp. 357-389—0003-9756/13/0000-900\$o7.50per art + \$o.1o per page (c) E.F.S., 2013. doi: 10.1017/S0003975613000209 
inequality, beliefs about fair inequality and judgements about existing inequality - and two dimensions-the magnitude of inequality and principles governing the distribution of resources (these concepts will be explained in further detail below). These different conceptions and dimensions have all been explored by comparative studies. This has resulted in a set of unconnected and disparate findings as the outcomes of studies examining, say, beliefs are not necessarily consistent with those examining judgements. A systematic review of these studies would greatly enhance insight into the accomplishments and shortcomings of this literature.

The relevance of examining specifically international comparative studies on views on inequality further lies in the variation across countries in the extent to which such views mirror actual inequalities (cf. Aalberg 2003; Lübker 2004; Osberg and Smeeding 2006; Forsé and Parodi 2007; Chapple et al. 2009; Dubet 20I I). If these views had been a perfect reflection of real inequalities everywhere, there would be little point in examining them comparatively across countries. The fact that they are not and that some studies have shown them to have an independent effect on other social outcomes (e.g. Mason I995; Gijsberts I 999) makes it worthwhile to explore the micro- and macro-level drivers of such views and to assess their social consequences cross-nationally.

Thus the current paper aims to provide a systematic review of international comparative studies on views on inequality in order to explore what shapes these views and what their social effects are. To my knowledge no study has yet conducted such a review. The current paper exclusively reviews international comparative studies examining people's views on inequalities of income relating to their own society. This means that single country studies, studies looking at views on racial or gender inequalities, studies examining perceptions of one's own income in relation to that of others, and studies exploring opinions on international income inequality will be omitted from the review. Studies on attitudes to redistribution and public welfare will also be excluded from the review as such attitudes are about public policy in the first place. These attitudes may be seen as important outcomes or correlates of views on inequality rather than constituting such views themselves. Although this review does not pretend to be exhaustive, it does claim to have covered the most important studies and to have arrived at a comprehensive assessment of the state of affairs in the field.

More specifically, this paper has three objectives. It firstly aims to develop a conceptual framework for the purpose of mapping and classifying the reviewed studies. Second, it discusses several 
influential theoretical perspectives explaining cross-country differences in views on inequality and assesses to what extent the findings of the reviewed studies support these approaches. Third, it identifies key omissions and shortcomings in the themes covered and approaches used by the reviewed studies.

\section{A framework classifying existing research}

I classify the comparative studies using a framework which includes the aforementioned conceptions and dimensions. As noted above, these conceptions involve perceptions, beliefs and judgements. Perceptions refer to subjective estimates of existing inequality (i.e. thoughts about what $i s)$. Beliefs are here defined as normative ideas about just inequality (i.e. thoughts about what should be). Judgements are understood here as normative evaluations of existing inequality (i.e. thoughts about how desirable or good the current situation is). The dimensions refer to the size of inequality and to the moral principles determining the allocation of income (Gijsberts I999; Verwiebe and Wegener 2000). People use these principles to develop ideas about fair rewards. Drawing on social justice literature (Miller I992, I999; Aalberg 2003) I identify the following competing principles ${ }^{\mathrm{I}}$ : merit/desert (achievement, skills and effort); workload (amount of work duties and job responsibility); equality; need; utility and ascription (membership of a social, kinship, ethnic, racial, religious or gender group). There is tension between these principles as a system of rewards based on merit is quite different from that based on equality or a system based on ascription. Each of the three conceptions can relate to both the size of inequality and the principles governing the allocation of incomes. Thus people make estimates of the magnitude of inequality and about the extent to which the existing distribution of income is based on merit, equality or ascription. Similarly, people have beliefs about a fair size of income inequality and about the principles that should determine income. People can also judge existing inequality to be too large (or too small) and to be too much a reflection of a certain principle of distribution. The framework can thus be visualized as a $3 \times 2$ matrix consisting of three conceptions and two dimensions (see the table).

The three types of conceptions are likely to be interrelated. Judgements of existing inequality, for instance, will depend on the gap between perceptions and beliefs. The larger the discrepancy between people's

\footnotetext{
I This list should not be interpreted as exhaustive.
} 
T A B L E

A classification of comparative studies examining views on inequalities as dependent or independent variables

\section{Studies examining views on inequality descriptively or as dependent variables}

\begin{tabular}{lll}
\hline \multicolumn{1}{c}{ Size of inequality } & \multicolumn{1}{c}{ Principles determining income } \\
\hline Perceptions & Kluegel et al. (1995a) & Marshall et al. (1999) \\
Örkény and Székelyi (2000) & Kreidl (2000) ${ }^{\mathrm{b}}$ \\
Aalberg (2003) & Örkény and Székelyi (2000) \\
Osberg and Smeeding (2006) & Redmond et al. (2002) \\
Kenworthy and McCall (2007) & Alesina and Glaeser (2004) \\
Forsé and Parodi (2007) & Paugam and Selz (2005) $^{\mathrm{b}}$ \\
& Forsé and Parodi (2007) \\
& Janmaat and Braun (2009) \\
& Dubet et al. (2010) \\
& Duru-Bellat and Tenret (2012) \\
\hline
\end{tabular}


Studies examining views on inequality descriptively or as dependent variables

\begin{tabular}{|c|c|c|}
\hline & Size of inequality & Principles determining income \\
\hline Beliefs & $\begin{array}{l}\text { Kelley and Evans (I993) } \\
\text { Arts } \text { et al. (I 995) } \\
\text { Mason (I995) } \\
\text { Svallfors (I997) } \\
\text { Gijsberts (2002) } \\
\text { Redmond et al. (2002) } \\
\text { Lübker (2004) } \\
\text { Kelley and Zagorski (2005) } \\
\text { Osberg and Smeeding (2006) } \\
\text { Forsé and Parodi (2007) } \\
\text { Janmaat and Green (2013) }\end{array}$ & $\begin{array}{l}\text { Kluegel and Mateju (I995) } \\
\text { Swift et al. (I995) } \\
\text { Wegener and Liebig ( } 1995) \\
\text { Marshall et al. (I999) } \\
\text { Örkény and Székelyi (2000) } \\
\text { Arts and Gelissen (200 I) } \\
\text { Redmond et al. (2002) } \\
\text { Aalberg (2003) } \\
\text { Kunovich and Slomczynski (2007) } \\
\text { Forsé and Parodi (2006) } \\
\text { Forsé and Parodi (2007) } \\
\text { Forsé (20Io) } \\
\text { Green and Janmaat (20I I) } \\
\text { Duru-Bellat and Tenret (2012) } \\
\text { Janmaat and Green (2013) }\end{array}$ \\
\hline
\end{tabular}


T A B L E (Continued)

Studies examining views on inequality descriptively or as dependent variables

\begin{tabular}{ll}
\hline \multicolumn{1}{c}{ Size of inequality } & Principles determining income \\
\hline Judgements & Mason (1995) \\
& Verwiebe and Wegener (2000) \\
& Suhrcke (2001) \\
& Redmond et al. (2002) \\
& Lübker (2004) \\
& Hadler (2005) \\
& Lübker (2007) \\
& Forsé and Parodi (2007) \\
& Kenworthy and McCall (2008) \\
& Forsé (2010) \\
Keller et al. (2010) & Dubet et al. (2010) \\
\hline
\end{tabular}


Studies examining views on inequality as independent variables

Size of inequality

Perceptions Arts et al. (1995): explaining beliefs about just inequalities;

Gijsberts (2002): explaining beliefs about just inequalities;

Kelley and Zagorski (2005): explaining beliefs about just inequalities

\section{Principles determining income}

Kluegel and Miyano (r 995): explaining attitudes on redistribution;

Suhrcke (200I): explaining judgements about income inequality;

Hadler (2005): explaining judgements about income inequality;

Dubet et al. (2010): explaining social cohesion;

Tóth and Keller (201 I): explaining attitudes on redistribution 
T A B L E (Continued)

Studies examining views on inequality as independent variables

Size of inequality

\begin{tabular}{lc}
\hline Beliefs & Kluegel and Miyano (I995): explaining \\
explaining & attitudes on redistribution; \\
judgements about & Mason (I995): explaining political \\
income inequality & distrust; \\
& Gijsberts (I999): explaining voting \\
& behaviour and legitimation of the \\
& political order; \\
& Verwiebe and Wegener (2000): explaining judgements \\
& about income inequality;
\end{tabular}




\section{Studies examining views on inequality as independent variables}

Judgements Lübker (2007): explaining

attitudes on redistribution;

Chapple et al. (2009):

explaining attitudes on

redistribution;

Keller et al. (2010): explaining

attitudes on redistribution;

Dubet et al. (2010): explaining social

cohesion;

Forsé (2010): explaining feelings

of micro-level justice;

Tóth and Keller (201 I): explaining attitudes on redistribution;

${ }^{a}$ These authors have created a construct representing the gap between perceptions of actual income and beliefs of just income and used this construct as a proxy for judgements of actual income inequality.

${ }^{\mathrm{b}}$ These authors have examined popular ideas about the causes of poverty. I understand such ideas to be a subset of perceptions of the extent to which various principles determine the distribution of income. 
estimates of inequality and their ideas about just inequality, the harsher their judgement of existing inequality is likely to be (Sen 2000; Aalberg 2003; Osberg and Smeeding 2006; Forsé and Parodi 2007). A strong link can also be suspected between perceptions and beliefs. People find it difficult to live with an inconsistency between how they perceive the real world and how they think the world should be, and they therefore gradually adjust their normative beliefs to their perceptions (Homans I 974). In other words, what they think "is" is likely to determine what they think "should be." Several studies have indeed found beliefs about legitimate income inequality to be strongly linked to perceptions of real inequality (e.g. Gijsberts 2002; Kelley and Zagorski 2005). Others however have noted discrepancies between perceptions and beliefs and have thus challenged the notion that people's morality is largely determined by how they experience and perceive the world (e.g. Forsé and Parodi (2007). Finally, the two dimensions are clearly interlinked. People who believe that the principle of merit should determine income are likely to accept much larger income differences than people who think that income should be based on equality. The suspected strong links between the three types of conceptions and the two dimensions justify the comprehensive nature of the proposed framework.

This framework builds on previous attempts to frame and classify the objects of study and research questions of social justice research (e.g. Jasso I989; Wegener and Steinmann I995; Jasso and Wegener I 997; Aalberg 2003). Jasso and Wegener (1997) propose four key questions to characterize and classify the research interests of this field. These questions broadly cover the three types of conceptions, the gap between real and ideal inequalities and the social consequences of perceived inequalities. Although helpful in delineating research in the field, the questions seem not to address the determinants of views on inequality and are not clearly articulating the three types of conceptions and the two dimensions. Aalberg (2003: 6), on the other hand, does distinguish between perceptions, beliefs and judgements, calling them perceptions, values and attitudes, respectively, but she does not identify the two dimensions. As the following will show, existing studies can be placed in all but one of the cells of the aforementioned $3 \times 2$ matrix. The proposed framework thus allows for a more precise classification and characterization of studies than previous frameworks.

The selected studies have been mapped onto the three conceptions and two dimensions (see the table above). The table also distinguishes between studies exploring views on inequality as dependent variables (26 in total) and those examining them as independent variables 
( 10 in total). The same study can appear several times depending on the number of conceptions and dimensions it addresses.

Three observations can be made. First, and most importantly, the vast majority of the studies appear to explore views on inequality as dependent variables. The emphasis on the question of what determines views on equality is surprising as it leaves the question as to the social relevance of such views unanswered (i.e. the "so what" question) (Kluegel et al. I995a). Moreover, the few studies that have used them as independent variables have not gone beyond exploring the (quite obvious) links of one type with other types of views on inequalities (Arts et al. I 995; Gijsberts 2002; Kelley and Zagorski 2005; Hadler 2005) or with attitudes to redistribution (e.g. Kluegel and Miyano I 995; Lübker 2007; Keller et al. 20 I0; Tóth and Keller 20 I I). I found only four comparative studies relating views on inequality to other social outcomes: Mason (r 995), Gijsberts ( I 999), Dubet, Duru-Bellat and Vérétout (2010) and Forsé (2010). Mason (1995) examined the effect of beliefs about just distributive principles on political trust. Controlling for individual background variables, he found that egalitarian convictions were negatively related to political trust in both PostCommunist and capitalist states, the effect being slightly stronger in the latter. In a comparative study of post-communist and Western states, Gijsberts (I999) found that egalitarian preferences (as measured by the ratio between perceived inequality and the inequality held to be legitimate) were negatively related to voting behaviour in Western countries but not in post-communist ones. Both studies thus found differences between West and East in the effect of views on inequality on other social outcomes. Dubet et al. (2010) observed that aggregate perceptions of a meritocratic society (i.e., the perception that people are rewarded for their efforts and talents) are positively related to social cohesion (as measured by a composite index comprising trust, tolerance and social capital). They also found aggregate judgements about inequality to be negatively related to social cohesion. In other words, the higher the percentage of people judging inequalities to be too large, the lower the social cohesion level. Finally, Forsé (2010) found a link between macro- and micro-views of social justice: people who believe that inequalities are too large and who think effort is generally not rewarded in society also tend to feel unfairly treated themselves regarding the degree to which their income reflects their own efforts.

The marginal scholarly interest in the wider social consequences of such views may partly be due to the reluctance to explain attitudes with attitudes (Dallinger 2010). After all, if views of inequality are 
related to attitudes like political trust and preferences on redistribution it is unclear what the direction of causality is and whether both sets of attitudes are not simply components of an overarching syndrome of attitudes and values. However, it is not just the "effect" of views on inequality on other attitudinal outcomes that has attracted little scholarly interest; the link with behavioural outcomes, where the causal arrow is much less disputed, has also hardly been explored (discounting the aforementioned studies by Gijsberts and Dubet et al.). This is remarkable as theoretically a strong relation can be suspected between views on inequality and behavioural outcomes such as voting and other forms of political participation. If people prefer large inequalities and judge existing inequality to be fair they do not have an incentive to mobilize politically in an effort to change the situation for the better (i.e. we can expect their participation levels to be low) (Lerner i 980). Moreover, the acknowledgement that correlations between attitudes say nothing about causality does not invalidate research into relations between attitudes. Again there can be good theoretical reasons for investigating these. It has for instance been proposed that people who believe current inequalities to be fair are also likely to hold negative views on the poor and other disadvantaged groups because of their conviction that these groups "get what they deserve" (ibid.). Evidence from the literature on "Belief in a Just World" (BJw) confirms both theoretical conjectures. ${ }^{2}$ Thus, Rubin and Peplau (I973, I975) found that people who believed in a just world displayed lower rates of political and social activism and lower levels of tolerance towards disadvantaged ethno-racial groups than people with more sceptical views. ${ }^{3}$ If comparative studies showed that views on inequality have an important independent effect on behavioural outcomes complementary to the effect of other conditions or if they revealed that such views correlate strongly with other attitudes to form distinct value complexes, the broader significance of views on inequality would surely be enhanced.

Second, there are almost no studies exploring the three conceptions and two dimensions all at once. So far I have identified only one study (Redmond et al. 2002) examining all three conceptions. Their study

\footnotetext{
2 This literature is relevant as people who believe in a just world must also believe that the distributions of income and wealth and the social and political institutions perpetuating them are just and should be maintained (DITTMAR and DICKINSON I993).

3 I wish to emphasize that the current paper neither expresses a normative prefer-
}

ence for distinct views on inequality nor argues that there is consensus among scholars and political thinkers as to which views are desirable. I recognize, for instance, that liberal thinkers such as Friedrich Hayek would prefer people to endorse a meritocratic system of distributive justice rather than to have strict egalitarian preferences. 
found that the gap between perceptions of factors actually determining incomes and beliefs about principles that should determine incomes was much larger in Eastern than in Western countries. They further found Eastern nations to be much more disapproving of existing inequalities than Western nations. This pattern of findings led the authors to postulate that it was the mismatch between their beliefs and their perceptions which at least partially explained the critical judgements of people in the East, a hypothesis that is in line with the aforementioned assumption that judgements are a function of perceptions and beliefs. Yet, as their study only presented descriptive statistics, it was not able to test this hypothesis fully. Thus, neither the presumed linkages between the three types of views on inequality nor those between the two dimensions, have been scrutinized adequately by existing empirical research.

Thirdly, no studies have been found examining judgements about the fairness of existing inequalities with regard to the distributive principles they reflect. The lack of such studies may well be due to the difficulty of capturing such judgements in public opinion surveys.

\section{Perspectives on cross-national differences in views on inequality}

As there are so few studies exploring views on inequality as independent variables affecting other social outcomes, a review of them would not be able to go much beyond reporting their results (as I have done for some of the aforementioned studies). For this reason and to give added value to the current review, I decided to focus on studies exploring views on inequality as dependent variables and to assess to what extent their findings support various perspectives on international differences in such views. Four such perspectives can be identified making different claims as to the magnitude and origin of cross-national variations in views of inequality. I present them as two pairs of contrasting perspectives: the modernist/functionalist versus the cultural/regimes approach and the micro versus macro approach.

In the modernist/functionalist perspective people's values and attitudes reflect the socio-economic conditions in their societies (Parsons I970; Inglehart and Welzel 2005). Societies in the same stage of economic development have many conditions in common and should therefore exhibit more or less the same cultural patterns. As Western societies have similar structural features-they are all affluent, post-industrial, knowledge- and market-based economies-their 
populations should broadly think in similar ways about a wide range of topics. Meritocratic beliefs and perceptions should be particularly strong in Western societies because of the requirements of their market economies (Miller I 992; Kelley and Zagorski 2005). Key features of such economies, such as competition (resulting in winners and losers) and a system of unequal rewards based on achievement (in order to motivate workers to work harder and improve their skills), would not function if people did not accept the idea that merit should determine income. By implication, populations of developing countries and non-market societies should have rather different views on inequality.

The cultural/regimes approach contrasts strongly with the modernist perspective in that it postulates sizeable cultural differences between Western countries and renounces the modernist idea of a singular path of socio-economic development. As Bendix (I964: I) puts it:

Belief in the universality of evolutionary stages has been replaced by the realization that the momentum of past events and the diversity of social structures lead to different paths of development, even where the changes of technology are identical.

In this approach conceptions of inequality should differ widely across Western countries as they are part of uniquely evolved cultures shaped by path-dependent institutions and social conditions. The cross-national variations in institutions and cultures ensure that people and politicians respond differently in terms of their attitudes and policies to the same challenges and processes.

Within this approach, we need to distinguish between a culturalist and a regimes perspective. Culturalists see culture and religion as exogenous, almost immutable entities fundamentally shaping values, attitudes and behaviour (e.g. Huntington I 996). Regime theorists such as Esping-Andersen (I990) and Hutton (I995), in contrast, believe that "regimes", as unique configurations of cultural, institutional and socio-economic conditions which frame people's ideas and behaviours, are not immune to outside pressures. They change in response to technological and socio-economic development. Unlike culturalists, regime theorists acknowledge the importance of social and political struggles about scarce resources in shaping the world of ideas. Regimes are considered the product of such struggles, the outcomes of which cannot be predicted in advance. Although regime theorists thus share the materialist outlook of modernists, they disagree with the latter about the degree to which values and perceptions can be predicted from socio-economic conditions. 
Esping-Andersen proposes the existence of three regimes characterizing the welfare states of Western countries. He discerns a liberal, a social democratic and a conservative regime, predominating in, respectively, the English-speaking, the Scandinavian and the original EU 6 countries. Countries with the liberal regime primarily rely on the market as allocator of resources. State intervention is comparatively low and so is the level of welfare benefits, which are meanstested and based on needs. The state plays a much larger role in the distribution of resources in the social democratic group. Welfare benefits are at a much higher level and are seen as fundamental citizenship rights. The welfare arrangements in countries with a conservative regime are based on the male breadwinner model. Benefits are income-related and linked to previous earnings. Traditional gender roles and patriarchal thinking predominate, making it difficult for women to pursue a career in the labour market. Gallie and Paugam (2000) proposed that these welfare regimes shape attitudes towards the unemployed. They argue that in countries with minimal, meanstested benefits-typically the countries with a liberal welfare regimethe unemployed are more likely to be stigmatised and to be viewed as undeserving than in countries with comprehensive, prior-income and insurance-based benefits-i.e. usually those characterised by a socialdemocratic and/or conservative welfare regime. Broadly, one could postulate that meritocratic convictions and inegalitarian preferences should prevail in the English-speaking countries, egalitarian beliefs in the Scandinavian countries and ascriptive beliefs discriminating between men and women in the original EU 6 countries.

A group of scholars claiming American "exceptionalism" in welfare policies and public opinion on inequality and redistribution represents a strand of literature that exemplifies the cultural perspective (e.g. Lipset and Bendix 1959; Alesina and Glaeser 2004). These scholars argue that, because Americans see their country as the land of unlimited opportunities in which everybody can "make it" as long as (s)he tries hard enough, they are much more tolerant of inequalities than Europeans, pass harsher judgements on the poor and are much less supportive of redistribution. In line with this argument, Lamont (2002) has observed that American workers, quite unlike their French counterparts, derive a sense of pride and dignity from merit rather than from solidarity with colleagues.

In the second pair of perspectives the contrast is between the micro and macro approach. In the former, cross-national differences in views on inequalities are simply the result of differences between 
populations in their composition (Haller et al. I995; Gijsberts 2002). In this view, only individual attributes such as occupational status, education, gender and age shape views on inequalities and nations differ in the composition of these attributes because of differences in economic structure (e.g. more service- or more manufacturing-oriented). Cross-national differences in views on inequalities will disappear when controlling for these individual characteristics. The micro approach is sometimes equated with the modernist/functionalist approach as both approaches link attitudes on inequality to socio-structural characteristics of societies (e.g. Kluegel, Mason and Wegener I995).

The macro perspective, in contrast, assumes that certain societal conditions can explain cross-country differences in views on inequality. These conditions are not mere aggregates of individual characteristicsas in the micro perspective-but genuine properties of societies, irreducible to individuals. As in the cultural approach, attitudes on inequality are also thought to differ substantially across Western countries. However, in contrast to that approach the macro perspective does not see such attitudes as reflecting distinct cultures but as properties that vary systematically with macro-level socio-structural conditions.

\section{Results}

So what can the findings of the disparate collection of international comparative studies, as presented in first part of Table, tell us about these four perspectives? I identified three groups of studiesmodernist/functionalist, culture/regimes and micro-macro studieswhich will be discussed in consecutive order below. This classification is thus informed by the perspectives outlined above. The last group includes studies representing both the micro and the macro perspective.

\section{Modernist/functionalist studies (comparing East and West)}

This group of studies broadly explores whether the experience of living under communism and exposure to its official rhetoric of equality have had a lasting impact on the attitudes of East European nations on issues of inequality and social justice (e.g. Kelley and Evans I 993; Arts et al. I995; Kluegel and Mateju I995; Gijsberts I999; Marshall et al. I999; Örkény and Székelyi 2000; Verwiebe and 
Wegener 2000; Suhrcke 2001; Gijsberts 2002; Redmond et al. 2002; Kelley and Zagorski 2005). Do people in the East continue to have very different attitudes on inequality or has the transition to democracy and the adoption of a market economy prompted an attitudinal change in the direction of Western public opinion? As the modernist perspective would clearly anticipate this fundamental transformation of socio-structural conditions to have produced a major attitude shift, the studies addressing this question can be said to assess the modernist perspective. Invariably these studies have used either the ISSP (modules I 987, I 992 and I 999) or the ISJP (modules I99 I and I996) as data sources. This literature has yielded the following findings.

(1) People in both regions share a preference for meritocratic and workload criteria as principles that should determine income. These attitudes seem to be stable. In other words, people everywhere believe that effort, achievement, skills and job responsibility should be more important in determining income than need or group membership (Marshall et al. I999; Örkény and Székelyi 2000; Redmond et al. 2002). These attitudes seem to be quite enduring in both regions as studies using the 1999 round of the ISSP (Redmond et al. 2002) and the I 996 round of the ISJP (Örkény and Székelyi 2000) find exactly the same pattern as those using the 1992 round of the ISJP (Marshall et al. I999; Örkény and Székelyi 2000).

(2) People in both regions have similar and enduring beliefs about which jobs should be paid more and which less. In other words, people in the East and West rank occupations in the same way regarding the income held to be legitimate for these occupations (Kelley and Evans I 993; Gijsberts I999; Gijsberts 2002). ${ }^{4}$ These beliefs seem to be stable as people made similar rankings in the 1987 and 1992 rounds of the ISSP (Gijsberts 2002). ${ }^{5}$

(3) People in the East have come to accept ever larger degrees of income inequality while the degree of income inequality held to be legitimate

4 These scholars used the following item in the ISSP survey: "Next, what do you think people in these jobs ought to be paid-how much do you think they should earn each year before taxes, regardless of what they actually get... (a) First, about how much do you think a bricklayer should earn?" <idem for other occupations $>$.

5 At first sight, beliefs about a legitimate hierarchy of earnings seem to fall somewhat outside my conceptual framework as they constitute neither beliefs about a fair size of inequality nor beliefs about legitimate principles determining income. However, if different occupations are seen as involving different degrees of achievement, effort and workload, beliefs about a legitimate income hierarchy could be interpreted as beliefs about legitimate principles determining income. 
in the West hardly changed. In fact, while Eastern nations preferred a much smaller degree of income inequality than Western nations thought right in I987 (Kelley and Evans I993; Gijsberts I999; Gijsberts 2002), by 1999 they favored much more inequality than Westerners held to be legitimate (Kelley and Zagorski 2005). In sum while beliefs about the principles that should govern pay appear to be quite stable in both regions, beliefs about legitimate degrees of income inequality are quite changeable in the East and relatively stable in the West.

(4) People in the East think that non-meritocratic factors (wealth, contacts and corruption) are much more important than meritocratic principles in determining actual incomes, while people in the West think the opposite is the case. The former seem to have grown more cynical over time. Thus, as to perceptions of the factors influencing existing incomes the reviewed studies find large differences between East and West (Marshall et al. I 999; Kreidl 2000; Örkény and Székelyi 2000; Redmond et al. 2002), which seem to have become more pronounced during the I 990 (as Örkény and Székelyi show comparing the I 99 I and 1996 rounds of the ISJP). As people in the East do believe that meritocratic principles should determine income, it can be concluded that there is a significant (and growing) gap in the East between reality as people see it and reality as people would want it to be. The decline in meritocratic perceptions in the East is difficult to reconcile with the increase in the degree of inequality held to be legitimate as one would not expect people to accept ever greater differences of income if at the same time they become more sceptical about the way these incomes are earned.

(5) People in the East have come to perceive ever larger degrees of actual income inequality while perceived income inequality has not changed much in the West. Following the exact same pattern as beliefs about legitimate inequality, perceived income inequality was lower in the East in the I 980 s and was higher in that region by comparison to the West by the end of the I990s (Kelley and Evans I993; Gijsberts I 999; Gijsberts 2002; Kelley and Zagorski 2005). Both Gijsberts (2002) and Kelley and Zagorski (2005) see a connection between these beliefs and perceptions, arguing that changes in beliefs resulted from changes in perceptions. This is consistent with the aforementioned notion that people's ideas about what "is" determine their ideas about what "should be".

(6) At the end of the I990s people in the East are much more disapproving of the degree of existing income inequality than people 
in the West. This is what Suhrcke (200I) and Redmond et al. (2002) concluded from the responses to the statement "income differences in your country are too large" in the I 999 round of the ISSP. As no study seems to have explored trends in normative judgements about existing inequality, it cannot be ascertained whether Eastern nations have become more or less critical of actual inequality. As noted before, Redmond et al. (2002) surmised that the more critical judgements of Eastern nations could well reflect the gap between their perceptions and their beliefs. However, Suhrcke (200I) found that people in the East still express more intolerant attitudes to existing inequality than people in the West after controlling for various determinants of such attitudes including perceptions of the principles governing incomes. This result, in his view, demonstrates that the communist past has left a pronounced imprint on people's attitudes.

Altogether the results of the comparative East-West studies are quite puzzling. It seems contradictory that the degree of income inequality believed to be legitimate has risen steeply in the East while at the same time people in this region have become more sceptical about the extent to which existing incomes reflect meritocratic principles and are more disapproving of the degree of existing inequality in their country than people in the West. The apparent contradiction can only be explained by assuming that people in the East had some ideal society in mind when answering the questions on legitimate incomes for a range of occupations-i.e. a society without corruption and nepotism.

\section{Cultural/regime studies}

A second group of comparative studies has investigated the cultures/regimes thesis. A distinction can be made between studies assessing Esping-Andersen's regimes approach (Svallfors I 993; I 997; Arts and Gelissen 200I; Luebcker 2004; Dubet et al. 2010; Green and Janmaat 20II; Janmaat and Green 20I3) and studies examining American exceptionalism (Alesina and Glaeser 2004; Osberg and Smeeding 2006). ${ }^{6}$ To begin with the former, some of these studies

\footnotetext{
${ }^{6}$ The only study testing the cultural perspective that I could not assign to either of these two groups is the one by WEBENER and LIEBIG (I995). They examine beliefs about just distributive principles in the United
}

States and East and West Germany and
explore the hypothesis that such beliefs are
rooted in distinct varieties of Protestantism
(Puritanism inspired by Calvinism in the US
and Lutherism in Germany). 
do find support for the notion that people's views on inequality are structured by welfare regimes, irrespective of the type of views they are examining (perceptions, beliefs or judgements). Thus, relying on the same ISSP data on fair earnings as Kelley and Evans, Svallfors (I997) finds that people in the Scandinavian countries (i.e. those characterised by a social-democratic regime) prefer much smaller income differences than people in the English-speaking (liberal) and German-speaking (conservative) countries. Surprisingly it is in the conservative countries and not in the liberal ones that people expressed the strongest non-egalitarian preferences. Svallfors moreover finds large differences within the liberal group with the US showing the most inegalitarian and Australia, Canada and New Zealand showing relatively egalitarian views. Similarly, using data of the I 999 round of the ISSP, Luebker (2004) and Dubet et al. (2010) find that the English-speaking nations express significantly lower rates of disapproval about the degree of existing income inequality (as indicated by the proportion of respondents agreeing with the statement "differences in income are too large") than the Scandinavian and the core EU countries. This is all the more remarkable as real income inequality is highest in the English-speaking countries (ibid. 2010). The English-speaking countries also distinguish themselves from the other societies regarding perceptions of the principles determining income. Whereas the majority of people in the former think that rewards are based on merit, only a minority believes that this is the case in other Western states (ibid. 2010: 173). ${ }^{7}$ Finally, examining beliefs about distributive principles, Arts and Gelissen (200I) find that support for the principle of equity (merit) is higher in Englishspeaking countries (Great-Britain and Ireland) than in the countries of mainland Europe. ${ }^{8}$

Using a different data source Janmaat and Green (20I3) also find relatively strong endorsement for the principle of merit in the English-speaking countries, but in their analysis the Scandinavian countries exhibit equally high levels of support for this principle. ${ }^{9}$ To complicate matters further, Green and Janmaat (20II: II3-II4) also

\footnotetext{
7 Based on the items in the ISsP I 999 wave: "Would you say that in your country people are rewarded for" (a) their efforts, (b) their skills and competences.

${ }^{8}$ Based on the item in the Evs 1999 wave: "What should a society provide in order to be considered just?" "Recognizing people on their merits."
}

9 Based on the items in the ISsP 2009 wave: "In deciding how much people ought to earn, how important should each of these things be in your opinion" (a) how hard he or she works at the job [merit]; (b) whether the person has children to support [need]. 
investigated such beliefs but their findings are different again. They observed large differences among English-speaking nations in opinions on whether merit or equality should be the guiding principle in determining pay. ${ }^{\text {10 }}$ Canadians and particularly Americans preferred merit over equality in much higher numbers than the British and Irish. In fact, contrary to Arts and Gelissen's findings, the British and particularly the Irish expressed relatively egalitarian views. Moreover, the differences among English-speaking nations were so large that all mainland European countries ranked between the United States and Ireland. As Arts and Gelissen and Green and Janmaat used different items to tap meritocratic beliefs (see footnotes 8 and ro), it can be concluded that country rankings on these beliefs appear to depend on the indicators used.

Moreover, even when authors make use of the same item from the same survey, conclusions can vary. Forsé and Parodi (2006), for instance, also examined responses to the EVS 1999 item on what a society should provide in order to be considered just, but unlike Arts and Gelissen, who emphasized cross-national differences, they highlighted the remarkable degree of consensus across countries on this issue. Across Europe people believed that satisfying everybody's basic needs [need], rewarding individual merit [merit] and reducing large income differences [equality] are all important non-competing principles and they were also in agreement regarding the order of these principles (i.e. first need, then merit and then equality) (ibid. 2006). Obviously, these conclusions run counter to the idea that people's normative beliefs reflect distinct regimes or cultures. They rather suggest the existence of a hierarchy of social justice principles independent of culture or other societal conditions (see also the next section).

Mixed support for the notion that attitudes on inequality are structured by welfare regimes also emanates from two studies (Paugam and Selz 2005; Janmaat and Braun 2009) examining perceived causes of poverty (which I interpret as perceptions of principles determining income). On the one hand, these studies found the tendency to attribute poverty to individual failure (e.g. laziness) to be particularly strong amongst the British, which is consistent with the proposition that meritocratic beliefs and perceptions are stronger

\footnotetext{
10 Based on the following item in the evs' wvs I 999-2004 "Imagine two secretaries, of the same age, doing practically the same job. One finds that one earns $£ 30$ a week more than the other. The better paid secretary,
}

however, is quicker, more efficient and more reliable at her job. In your opinion is it fair or not fair that one secretary is paid more than the other?" 
in countries with a liberal welfare regime. On the other hand, they found perceptions of the causes of poverty and unemployment to be highly fluctuating and to be strongly related to periods of economic growth and recession. The dynamic character of these perceptions is difficult to reconcile with the idea that such perceptions are shaped by long-term structural differences in welfare arrangements across countries.

In addition to examining aggregate levels of attitudes on inequality, Svallfors (I997) explored whether micro-level determinants of such attitudes would differ by regime type. He found that men, white collar workers, and retired people preferred larger income differences than women, blue collar workers and the younger generations in all four countries of his research (US, Australia, Germany and Norway). In other words the same cleavage structure applied across the board. In a similar vein, Swift et al. (I 995) found beliefs about just distributive principles to be determined by the same social divides across the US, Great Britain and Germany. Exploring differences between East and West, Verwiebe and Wegener (2000) and Surhrcke (200I), moreover, observed that attitudes in both regions are structured quite similarly. Thus, there is no support for the claim that not only aggregate attitudes on inequality but also social cleavages generating these attitudes differ across regimes.

The two studies examining American exceptionalism diverge in their findings. Osberg and Smeeding (2006) used ISSP I 999 data on occupational earnings to explore the attitudes of Americans, British, French, Norwegians and Canadians. They find that Americans do not differ from the other four nations in their perceptions of the degree of wage inequality and beliefs about legitimate pay differences, which is not consistent with the popular thesis that Americans are unique in their views on matters of inequality and social justice. However, they do find the attitudes of Americans to be much more polarized than those of the other nations. Interestingly, Osberg and Smeeding's findings on legitimate pay differences contrast sharply with those of Svallfors. While both authors rely on the same items on fair earnings, they used different rounds of the ISSP and developed different indicators to measure beliefs on fair earnings. ${ }^{\text {II }}$ The contrasting findings are another sobering reminder that cross-country patterns can vary greatly depending on the indicators used and time the data

\footnotetext{
${ }^{\text {I }}$ While Svallfors (I997: 462) constructed an index representing the ratio of the three top to the three bottom earnings in

each country, Osberg and Smeeding's (2004: 463) measure was simply the ratio of the maximum to the minimum earning.
} 
was collected. Drawing on WVS I 999-2004 data, Alesina and Glaeser (2004) examined attitudes on the sources of poverty. In contrast to Osberg and Smeeding they do find that Americans stand out: Americans agreed in much higher numbers with the statement that people are poor "because of laziness and lack of willpower" than European nations did (even distinguishing themselves sharply from the British who, as shown by the two aforementioned studies, also referred to laziness in relatively high numbers). Whether Americans express very distinct opinions thus appears to depend on the object of the perceptions under investigation.

\section{Micro-macro studies}

The last group of studies relates to the issue of whether cross-national differences in views on inequality are the product of compositional differences (i.e. the micro perspective) or of variations in macro-level conditions (i.e. the macro perspective). Gijsberts' (2002) findings clearly support the micro perspective. She found that differences between countries in beliefs about legitimate income inequality stayed the same after controlling for social position but were markedly reduced after controlling for perceptions of the degree of inequality. Thus crossnational differences in beliefs can be explained by compositional differences in perceptions. It could be argued, however, that this merely shifts the problem as it in turn begs the question of why these perceptions differ across countries. Nonetheless, Verwiebe and Wegener's (2000) study provides additional backing for the micro perspective. They found Eastern European nations to have become more similar over time in the gap between perceptions of existing inequalities and beliefs about just inequalities. Individual characteristics explaining these gaps grew in importance while the influence of specific macro-level transition trajectories decreased.

The development of statistical techniques and software enabling multi-level analysis undoubtedly explains the growing number of studies assessing the impact of macro-level conditions such as income inequality, meritocracy and ethno-racial diversity. Proceeding from Sen's (2000) idea that people share the same concept of social justice cross-nationally and compare the existing inequality in their country to this universal benchmark, Luebker (2004), for instance, explores whether people in unequal countries have more critical judgements about existing inequalities than people in more equal countries. He 
indeed finds such a relationship but only after controlling for different welfare regimes. In other words, while judgements vary considerably across regimes, within each regime people are more critical of inequalities the larger these inequalities are. Cross-national differences in judgements of inequality would thus seem to be a reflection of both distinct cultures and socio-structural conditions. As culture and structure both represent macro-level conditions, Lübker's findings can be seen as supporting the macro perspective. Consistent with Lübker's results, Keller et al. (2010), who analysed data of the Special 2009 Eurobarometer on social exclusion, also find no direct relationship between actual income inequalities and judgements about existing inequalities. In other words, people in more unequal countries do not necessarily think that inequalities are too large, refuting Sen's assumption that there should be a straight connection between actual and evaluated inequalities.

Hadler (2005) also focuses on judgements about existing inequalities. He tests a whole battery of macro and micro level determinants of such judgements using data of the 1999 round of the ISSP. Three groups of macro-level determinants are identified: structural characteristics (prosperity and income inequality), heritages (communist past and dominant religion) and dominant ideologies (functionalistic, meritocratic and egalitarian ideologies and the dispersion of values on each of these ideologies). Due to limitations of the sample Hadler could only test two determinants simultaneously. He finds that the model including functionalistic ideology and homogeneity of functionalistic values performed best in terms of explaining the cross-national variance in judgements. Unfortunately his study does not present models combining determinants from different groups. Consequently we cannot tell from his study whether the ideological and heritage conditions are more or less important than the structural ones in accounting for crosscountry variations in the outcome of interest.

In contrast to Sen, Duru-Bellat and Tenret (2012) argue that people's conceptions of social justice are likely to vary across countries. She postulates that relatively unequal societies need stronger ideologies justifying these inequalities to retain social cohesion. A meritocratic ideology-i.e. a claim that the allocation of resources and rewards in society is fair as it occurs strictly on the basis of effort, achievement and skills-fills this legitimating role and can thus be expected to be strongest in the most unequal societies. Her study indeed finds that both meritocratic perceptions (i.e. the view that in one's country rewards are allocated on the basis of effort and skills) and meritocratic beliefs (i.e. the conviction 
that education and training ought to determine one's income) are most prevalent in societies with the highest degrees of income inequality. ${ }^{\mathrm{I2}}$

Other research supporting the macro perspective is the study by Kunovich and Slomczynski (2007). They devised a measure for a society's actual meritocracy based on the degree to which income corresponds to educational attainment. Meritocratic beliefs were tapped with a construct based on a battery of items in the ISSP on criteria determining pay. They found meritocratic beliefs to be stronger in more meritocratic societies controlling for a number of country-level and individual-level variables. This supported their proposition that "the degree of actual meritocracy affects attitudes towards such a system because individuals realize that earned economic rewards are determined by merit" (ibid.: 65I). Among the other country-level variables, they found educational stock (measured as the percentage of the population with tertiary level qualifications) to be positively related to meritocratic beliefs, and prosperity (GNP per capita) and communist legacy to be negatively related to such beliefs.

In sum, whatever particular macro-conditions they highlight, cultural or socio-structural, the four studies above all share the assumption that certain societal characteristics have an independent and complementary effect on attitudes on inequality in addition to micro-level determinants. They all find that some macro-level condition influences these attitudes.

\section{Discussion}

The previous section has already partly assessed the extent to which the findings of the reviewed studies support the four aforementioned perspectives. This section assesses the explanatory power of these perspectives more comprehensively. In the process key omissions and shortcomings of the reviewed studies will be identified. To begin with the first-named group of studies, these studies are particularly well suited to testing the modernist vis-à-vis the cultural perspective. If the modernist perspective is right we would expect post-communist nations to have become more similar to Western nations in their views on inequality from the moment they adopted free market economies.

\footnotetext{
12 The authors devised a scale of meritocratic perceptions based on the ISsP items "Would you say that in your country people are rewarded for their efforts?" and "Would you say that in your country people are
}

rewarded for their skills?" Meritocratic beliefs were tapped with the item "In deciding how much money people ought to earn, how important should be [...] education and training?" 
The cultural perspective would expect to find lasting differences because of the different historical experiences of both regions.

As a whole the pattern of results seem to provide slightly more support for the modernist perspective. Firstly, attitudes have changed much more dramatically in the East, particularly regarding perceptions of existing inequalities and beliefs about just inequalities. This is what the modernist perspective would expect given the profound changes in socio-economic conditions in this region. However, the changes have been so dramatic that the East has actually "overtaken" the West in perceived inequalities and in inequalities held to be just. By the end of the I 990 s people in the East both see and accept larger inequalities than people in the West. At first sight this more recent divergence seems to be more difficult for the modernist perspective to explain. Yet, the profound attitudinal change in the East may after all be understandable in view of the sudden inequalities, unusual opportunities and new uncertainties generated by the vagaries of the transition process. Indeed, drawing on Hirschman and Rothschild's theory on well-being in societies experiencing rapid development, Grosfeld and Senik (2009) show that people in Poland grew more intolerant of income inequalities towards the end of the r 990 s as soon as disenchantment with the opportunities offered by the new social order set in. Kelley and Zagorski (2005: 29) argue that once this period of unsettledness has passed and market conditions have stabilized, "leaving fewer unusual opportunities", views on inequality will become more similar to those in Western countries. In this respect it will be interesting to explore data from the 2009 module on inequalities of the ISSP to see whether their prediction has come true.

Secondly, people in both regions had similar beliefs about legitimate distributive principles and about legitimate earning hierarchies in the I 980 s when their economic systems were still very different. In the first instance this finding does not seem to support either of the two perspectives. However, the market economies of the West and the state command economies of the East did have some basic structural features in common. Both were industrial societies with essentially similar divisions of labour and therefore similar work duties and status hierarchies (Kelley and Evans I 993). Moreover, pushed by the exigencies of industrialization, the Soviet leadership soon abandoned the radical egalitarianism of the I 920 s and replaced it with its own brand of meritocratic ideology which promoted the idea that differences in income were legitimate as long as people had equal opportunities and income was based on desert-type criteria (Mason I995; Marshall et al. I999). Thus the similarities in work 
roles and ideologies justifying unequal rewards can explain why people in both regions shared the aforementioned beliefs despite their different systems of production and capital ownership. If we understand the modernist perspective in the broadest sense-i.e. as a claim that societies in roughly the same stage of development (agrarian, industrial, post-industrial) should exhibit the same attitudinal patterns-then the similarity of beliefs across East and West is consistent with it.

Yet, the patterns on judgements about existing inequalities seem to be more in line with the cultural perspective as people in the East were found to be considerably more disapproving of existing inequality in their societies than people in the West. This finding does suggest that the experience of communism has left people in the East with strong egalitarian preferences despite the adoption of Western style market economies. It is also difficult to reconcile with the finding that people in the East have come to think ever larger degrees of income inequality to be legitimate. Unfortunately no study has addressed these contradictory findings by examining all three types of views (perceptions, beliefs and judgements) simultaneously and analyzing their interrelations. This is a major omission in the literature. It could be argued that the findings can be squared if people in the East do accept large inequalities if society were fair but remain very critical of existing inequalities as long as they perceive society to be very unfair. This conjecture could be tested by a study examining whether judgements of existing inequalities result from the gap between beliefs about the principles that should determine incomes and perceptions of the principles actually determining incomes. To my knowledge no study has done this yet.

Another shortcoming in the East-West studies is the underexploitation of existing datasets regarding trends in views on inequality. Despite the inclusion of items tapping judgements about existing inequalities, beliefs about just principles determining incomes and perceptions of criteria determining actual incomes in all four rounds of the ISSP (I987, I992, I 999 and 2009), no study has explored developments in any of these views over time. Such studies could explore whether trends in views on the magnitude of inequalities are matched by trends in views on the sources of inequality and help shed light on the aforementioned set of contrasting findings.

The second group of studies offered only marginal support for the cultural uniqueness thesis. On the one hand, cross-country patterns were found on beliefs about fair income differences and fair distributive principles which matched Esping-Andersen's welfare regimes. On the other hand there were studies examining the exact same beliefs 
(but relying on different data sources and indicators) which did not find country differences corresponding to any cultural traditions assumed to characterize (groups of) Western countries. Moreover, views on inequality appeared to be structured quite similarly across a variety of countries in terms of the determinants of such views. Given the contrasting findings yielded by different items, different data sources and different indicators, it is advisable that future research testing the cultural thesis makes maximum use of triangulation. Only if the same cross-country pattern emerges irrespective of the data, items and indicators used can one be reasonably sure about the robustness of the findings. Of course, the suggestion of triangulation is relevant to practically all research relying on survey data.

My second recommendation relates specifically to research testing the modernist thesis versus the cultural one. It could be argued that only research using a wide selection of countries, including both developed and developing ones, can properly assess which of the two theses has the upper hand in explaining cross-country differences in views on inequality. Only such research can explore whether countries with similar economies have more in common in terms of these views than countries with different economies. If such research were to find that views on inequality broadly coincided with a country's economy, then the modernist thesis would be supported. If in contrast it found that countries had very different and stable views on inequality irrespective of the state and nature of their economies, then the cultural thesis would have more explanatory power. Remarkably, none of the reviewed studies has used a broad selection of countries despite the availability of relevant public opinion data with world-wide coverage, such as that of the World Values Survey. This is a key omission in the literature.

More work can also be done to test whether cross-national variation in views on inequalities is only or mainly due to compositional differences or to macro-level conditions. Over time research of the type conducted by Verwiebe and Wegener (2000) would seem to be particularly relevant as there are good reasons to postulate a decrease in the importance of macro-level factors (and therefore a concomitant increase in the explanatory power of individual-level conditions). First, because of their adoption of liberal democracy and a free market economy, Eastern states have become much more similar to Western states in socio-economic and political terms and it can therefore be expected that the role that societal conditions play in accounting for East-West differences in views on inequality has diminished. Second, global economic integration and the expansion of the mass media are 
likely to have undermined distinctive national cultures and may therefore have led to ever smaller differences between countries by comparison to differences within countries in public opinion. The 2009 round of the ISSP on social inequality and the 2010 wave of the World Values Survey provide researchers with excellent opportunities to investigate these propositions as the data from these surveys can be compared to earlier rounds.

In addition, it is recommended that studies investigating macrolevel conditions explore to what extent views on inequality are shaped by distinct cultures or by structural characteristics of a continuous nature This will be a challenging task as the variation in the latter will often run parallel to variation in the former. For instance, income inequality is relatively high in countries said to have a meritocratic culture while it is low in countries espousing an egalitarian culture. However, disentangling the impact of these two different conditions is vital as it provides us with clues as to the manipulability of views on inequality. If such views respond in a linear fashion to changes in macro-level socio-structural conditions, they are predictable and amenable to change by reforms seeking greater social justice. If by contrast they are deeply rooted in distinct cultures or are a reflection of certain welfare regimes, it would seem much more difficult to make them change and go in a particular direction by means of public policy.

I conclude by reiterating the point about the wider social relevance of views on inequality. It is disappointing that so few studies have examined the social consequences of such views. Although several studies have done a good job in demonstrating that beliefs about distributive principles have a strong effect on a variety of social outcomes, net of the effect of other individual-level conditions (e.g. Kluegel and Miyano I995; Mason I995; Gijsberts I999), there is very little research using macro-level controls such as real income inequality. To my knowledge only Lübker (2007) has done so. He found that judgements about existing inequality were the only variable showing a significant impact on demands for redistribution in an analysis including income inequality and country dummies as control variables. More research of this type is needed to demonstrate the independent and complementary effect that views on inequality can have on various social outcomes.

I suggest two reasons for the scarcity of comparative studies assessing views on inequality as independent variables. Firstly, the single-country character of most research may be due to the micro-level character of such views. In other words, as these views are properties of individuals their consequences can be explored within countries. The findings of 
single-country studies have not been reported here as the current review only included comparative studies. No matter how valuable the findings of such studies are, there is still good reason to examine the consequences of views on inequality cross-nationally as the effect of such views may differ across countries (as demonstrated by the aforementioned studies of Mason and Gijsberts) and depend on certain macro-level properties. As noted before, another reason why there are so few comparative studies examining views on inequalities as exogenous factors may be that causality cannot be established in cases where such views are used to explain other attitudinal outcomes. Whatever the reason for the dearth of such studies, the absence of a strong field of research highlighting the relevance of views on inequality for other social outcomes may explain why scholarly interest in the topic seems to have dwindled in the last few years.

\section{Acknowledgments}

I am grateful to Andy Green and Christine Han for their constructive comments on earlier drafts of this article. This study is part of the research agenda of LLAKES. LLAKES is an ESRC-funded research center (Grant RES-594-28-000I).

\section{BI BLIOGRAPHY}

Aalberg Toril A., 2003. Achieving Fustice: Comparative Public Opinions on Income Distribution (Leiden, Brill).

Alesina Alberto and Edward L. Glaeser, 2004. Fighting Poverty in the US and Europe: A World of Difference (Oxford, Oxford University Press).

Arts Wil, Piet Hermkens and Peter van WIJCK, I995. "Justice Evaluation and Income Distribution in East and West", in Kluegel James R., Mason David S., and Wegener BERND, eds., Social Fustice and Political Change: Public Opinion in Capitalist and Post-Communist States (New York, Aldine de Gruyter: I3 I-I 50).

Arts Wil and John Gelissen, 200 I. "Welfare States, Solidarity and Justice Principles: Does the Type Really Matter", Acta Sociologica, 44: 283-299.

Bendix Reinhard, I964. Nation-building $\xi^{\circ}$ Citizenship: Studies of our Changing Social Order (New York, Barns and Noble).
Chapple Simon, Michael Förster and John Martin, 2009. "Inequality and well-being in OECD countries: What do we know?", paper presented at the 3 rd OECD World Forum on "Statistics, Knowledge and Policy" Charting Progress, Building Visions, Improving Life, Busan, Korea - 27-30 October 2009.

Dallinger Ursula (2010). "Public Support for Redistribution: What Explains CrossNational Differences?", Fournal of European Social Policy, 20(4): 333-349.

Dittmar Helga and Julie Dickinson, i 993. "The Perceived Relationship Between the Belief in a Just World and Sociopolitical Ideology”, Social Fustice Research, 6: I I-23. Dubet François, 20I I. "Régimes d'inégalité et injustices sociales ", Sociologies [En ligne], Débats, Penser les inégalités, mis en ligne le i 8 octobre 201 I, consulté le o8 avril 20I3. URL: http://sociologies.revues. org/ 3643 . 


\section{SUBJECTIVE INEQUALITY}

Dubet François, Marie Duru-Bellat et Antoine VéRÉTOUT, 20I O. Les sociétés et leur école. Emprise du diplôme et cohésion sociale (Paris, Le Seuil).

Duru-Bellat Marie and Elise Tenret, 20 i 2. "Who is for Meritocracy? Individual and Contextual Variations in the Faith", Comparative Education Review, 56(2): 223-247.

Esping-Anderson Gøsta, i990. The Three Worlds of Welfare Capitalism (Princeton, Princeton University Press).

Forsé Michel, 20ı o. "Macro-inequalities and micro-justice", in Max Haller, Jowell R. Roger, and Tom W. Sмith, eds., The International Social Survey Programme I 984-I 999: Charting the Globe (Routledge, London).

Forsé Michel and Maxime PArodi, 2006. " Justice distributive: la hiérarchie des principes selon les Européens ", Revue de l'OFCE, 98: 213-244.

-, 2007. "Perception des inégalités économiques et sentiment de justice sociale ", Revue de l'OFCE, 2007/3 n $\mathrm{n}^{\circ}$ 102, p. 483-540. DOI: I0.39I 7/reof. I02.0483

Gallie Duncan and Serge Paugam, 2000. "The Experience of Unemployment in Europe: The Debate", in Gallie Duncan and Serge Paugam, eds., Welfare Regimes and the Experience of Unemployment in Europe (Oxford, Oxford University Press: I-22).

Gijsberts Mérove, i 999. The Legitimation of Inequality in State-Socialist and Market Societies, I987-I996 (Amsterdam, Thela Thesis).

-, 2002. "The Legitimation of Income Inequality in State-Socialist and Market Societies", Acta Sociologica, 45: 269-285.

Green Andy and Jan Germen JanmaAt, 20 I I. Regimes of Social Cohesion: Societies and the crisis of globalization (Basingstoke, Palgrave Macmillan).

Grosfeld Irena and Claudia Senik, 2009. " La montée de l'aversion à l'inégalité. Du temps des anticipations au temps de la déception ", Revue économique, 6o(3).

Hadler Markus, 2005. "Why do People Accept Different Income Ratios? A Multilevel Comparison of Thirty Countries", Acta Sociologica, 48: I3 I-I 54 .

Haller Markus, Bogdan Mach and Heinrich ZwICKY, I 995. „Egalitarismus und Antiegalitarismus zwischen gesellschaftlichen Interessen und kulturellen Leitbildern", in Peter Müller Hans and Wegener Bernd, eds., Soziale Ungleichheit und soziale Ger- echtigkeit (Opladen, Leske und Budrich: 22 I-264).

Homans George C., i 974. Social Behavior. Its Elementary Forms, rev. edn. (New York, Harcourt Brace Jovanovich).

Huntington Samuel P., (1996). The Clash of Civilizations and the Remaking of World Order (New York, Simon and Schuster).

Hutton Will, i995. The State We're In (London, Jonathan Cape).

Inglehart Ronald and Christian Welzel, 2005. Modernization, Cultural Change and Democracy: The Human Development Sequence (Cambridge, Cambridge University Press).

JanmaAt Jan Germen and Robert Braun, 2009. "Diversity and Postmaterialism as Rival Perspectives in Accounting for Social Solidarity: Evidence from International Surveys", International Fournal of Comparative Sociology: 39-68.

Janmaat Jan Germen and Andy Green, 2013. "Skills Inequality, Adult Learning and Social Cohesion In The United Kingdom", British Fournal of Educational Studies, 6I(I): 7-24.

JAsso Guillermina, I 989 . "The Theory of the Distributive Justice Force in Human Affairs: Analyzing the Three Central Questions”, in Berger Joseph, Morris Zelditch, Jr. and Bo Anderson, (eds.), Sociological Theories in Progress: New Formulations (Newbury Park, Sage: 354-387).

Jasso Guillermina and Bernd Wegener, I 997. "Methods for Empirical Justice Analysis: Part I”, Framework, Models and Quantities', Social Fustice Research, Iо: 393-430.

Keller Tamas, Marton Medgyesi and Istvan То́тн, 20ıо. "Analysing the Link Between Measured and Perceived Income Inequality in European Countries", research Note No. 8. Available at http://www.tarki.hu/en/ research/observatory/rn8_2009_sso.pdf. Accessed 29 August 2012.

Kelley Jonathan and M. D. R. Evans, M.D. R., I 993. "The Legitimation of Inequality: Occupational Earnings in Nine Nations", American Fournal of Sociology, 99: 75-I25.

Kelley Jonathan and Krzysztof ZAGORSKI, 2005. "Economic Change and the Legitimation of Inequality: The Transition from Socialism to the Free Market in CentralEast Europe', Research in Social Stratification and Mobility 22: 32 I-366.

Kenworthy Lane and Leslie McCall, 2007. "Inequality, Public Opinion and Redistribution”, Socio-Economic Review, 6: 35-68. 


\section{JAN GERMEN JANMAAT}

Kluegel James R., Gyorgy Csepeli, Tamas Kolosi, Antal ÖRkény and Maria NeménYI, I 995. "Justice Beliefs and Support for the Welfare State in Advanced Capitalism", in James R. Kluegel, Mason David S. and Wegener Bernd, eds., Social Fustice and Political Change: Public Opinion in Capitalist and Post-Communist States (New York, Aldine de Gruyter: 8I-I08).

Kluegel James R., David S. Mason and Bernd Wegener, I 995. "The International Social Justice Project”, in James R. Kluegel, Mason David S. and Wegener Bernd, eds., Social fustice and Political Change: Public Opinion in Capitalist and PostCommunist States (New York, Aldine de Gruyter: I-I4).

Kluegel James R. and Petr Mateju, i 995. "Egalitarian vs. Inegalitarian Principles of Distributive Justice”, in James R. Kluegel, Mason David S. and Wegener Bernd, eds., Social Fustice and Political Change: Public Opinion in Capitalist and Post-Communist States (New York, Aldine de Gruyter: 209$238)$.

Kluegel James R. and Masaru Miyano, I 995. "Justice Beliefs and Support for the Welfare State in Advanced Capitalism" in JAmes R. Kluegel, Mason DAvid S. and Wegener Bernd, eds., Social fustice and Political Change: Public Opinion in Capitalist and Post-Communist States (New York, Aldine de Gruyter: 8 I-ro8).

Kreidl Martin, 2000. "Perception of Poverty and Wealth in Western and Post-Communist Countries", Social Fustice Research, I3: I 5 I- I 76 .

Kunovich Sheri and Kazimierz M. SLOMCZYNSKI, 2007. "Systems of Distribution and a Sense of Equity: A Multilevel Analysis of Meritocratic Attitudes in Post-Industrial Societies”, European Sociological Review, 23: 649-663.

Lamont Michèle, 2002. La dignité des travailleurs (Paris, Presses de Sciences Po).

Lerner Melvin, i 980 . The Belief in a Fust World: A Fundamental Delusion (New York, Plenum)

Lipset Seymour M. and Reinhard Bendix, 1959. Social Mobility in Industrial Society (Berkeley, University of California Press).

LüBKER Malte, 2004. "Globalization and Perceptions of Social Inequality”, Working Paper No. 32 (Geneva, International Labour Organization).

-, 2007. "Inequality and the Demand for Redistribution: Are the Assumptions of the New Growth Theory Valid?”, SocioEconomic Review, 5: I I 7-I48.

Marshall Gordon, Adamn Swift, David Routh and Carole Burgoyne, i 999. "What Is and What Ought to Be: Popular Beliefs About Distributive Justice in Thirteen Countries”, European Sociological Review, I 5: 349-367.

Mason David S., I 995). "Justice, Socialism, and Participation in the Post-Communist States" in Kluegel James R., David S. Mason and Bernd Wegener, eds., Social Fustice and Political Change: Public Opinion in Capitalist and Post-Communist States (New York, Aldine de Gruyter: 49-80).

Miller David, I992. "Distributive Justice: What the People Think", Ethics I02: 555-593. -, r999. Principles of Social Fustice (Harvard, Harvard University Press).

ÖRKÉNY Antal and Maria SZÉKELYI, 2000. "Views on Social Inequality and the Role of the State: Posttransformation Trends in Eastern and Central Europe", Social Fustice Research, 13: 199-2 18.

Osberg Lars and Timothy Smeeding, 2006. “'Fair' Inequality? Attitudes towards Pay Differentials: The United States in Comparative Perspective", American Sociological Review 7I, 450-473.

Parsons Talcott, I970. The Social System (London, Routledge).

Paugam Serge et Marion Selz, 2005. "La perception de la pauvreté en Europe depuis le milieu des années I 970 ", Economie et Statistique, Vols. 383-385: 283-305.

Redmond Gerry, Sylke Viola Schnepf and Marc Suhrcke, 2002. "Attitudes to Inequality After Ten Years of Transition”, Innocenti Working Paper No 88 (Florence, UNICEF Innocenti Research Centre).

Rubin Zick and Anne Peplau, i 973. "Belief in a Just World and Reactions to Another's Lot", Fournal of Social Issues, 29: 73-93.

—, I 975 . "Who Believes in a Just World?", Fournal of Social Issues, 3 I: 65-89.

Sen Amartya, 2000. "Merit and Justice", in Kenneth Arrow, K., Samuel Bowlesand and Steven Durlauf, eds., Meritocracy and Economic Inequality (Princeton, Princeton University Press: 5-I6).

Suhrcke Marc, 200I. "Preferences for Inequality: East vs West" (Innocenti Working Paper No 89).

Svallfors Stefan, r 993 . "Dimensions of Inequality: A Comparison of Attitudes in Sweden and Britain", European Sociological Review, 9(3): 267-287. 


\section{SUBJECTIVE INEQUALITY}

—, I997. "Worlds of Welfare and Attitudes to Redistribution: A Comparison of Eight Western Nations”, European Sociological Review, I3: 283-304.

Swift Adam, Gordon Marshall, Carole BurGoyne and David Routh, I 995. "Distributive Justice: Does it matter what the Peaople Think" in Kluegel James R., David S. Mason and Bernd Wegener, eds., Social Fustice and Political Change: Public Opinion in Capitalist and Post-Communist States (New York, Aldine de Gruyter: I 5-48).

Tóth Istvan G. and Tamas Keller, 20I I. "Income distributions, inequality perceptions and redistributive claims in European Societies”, Gini Discussion Paper 7, Available at: http://www.gini-research.org/system/ uploads/244/original/DP_7_-_Toth_Kel-ler. pdf (accessed 9 April).

Verwiebe Roland and Bernd Wegener, 2000. "Social Inequality and the Perceived

\section{Résumé}

L'étude fait le tour des comparaisons internationales qui ont analysé les opinions sur l'inégalité. On peut les classer à partir de trois conceptions de l'inégalité et de deux dimensions. On obtient en fait quatre modèles qui rendent compte des différences entre nations : le moderniste, le culturaliste, la perspective micro et la perspective macro. Les données comparatives pour les pays ex-communistes et les pays occidentaux s'accordent mieux avec une perspective moderniste que culturaliste. Les études comparatives ont fort peu traité les jugements sur l'inégalité comme variables indépendantes ayant un impact sur d'autres attitudes et comportements sociaux. La pertinence sociale de ce champ d'études serait augmentée si davantage d'études montraient que les jugements sur l'inégalité ont des effets sociaux qui s'ajoutent à ceux des inégalités objectives.

Mots clés : Perception des inégalités ; Justice sociale ; Comparaison internationale ; Perspective moderniste ; Régimes de protection sociale.
Income Justice Gap”, Social fustice Research I3: I 23 I 49 .

Wegener Bernd and Stefan Liebig, i 995. "Dominant Ideologies and the Variation of Distributive Justice Norms: A Comparison of East and West Germany and the United States", in Kluegel James R., David S. Mason and Bernd Wegener, eds., Social Fustice and Political Change: Public Opinion in Capitalist and Post-Communist States (New York, Aldine de Gruyter: 239-262).

Wegener Bernd and Suzanne SteinMANN, I 995. "Justice Psychophysics in the Real World: Comparing Income Justice and Income Satisfaction in East and West Germany”, in Kluegel James R., David S. Mason and Bernd Wegener, eds., Social Fustice and Political Change: Public Opinion in Capitalist and PostCommunist States (New York, Aldine de Gruyter: I 5 I-I 75).

\section{Zusammenfassung}

Dieser Beitrag interessiert sich für internationale vergleichende Studien, die die Anschauungen über Ungleichheit zum Thema haben. Diese Studien lassen sich in drei Konzepte und zwei Dimensionen von Ungleichheit einteilen. Daraus entstehen vier Modelle, die die unterschiedlichen nationalen Betrachtungsweisen von Ungleichheit erklären: die modernistische Perspektive, die kulturelle Perspektive, die Mikroperspektive und die Makroperspektive. Die vergleichenden Angaben ehemaliger kommunistischer und westlicher Länder stimmen eher mit der modernistischen als mit der kulturalistischen Perspektive überein. Nur wenige der vergleichenden Studien scheinen Ungleichheiten als unabhängige Variablen zu verstehen, die zu anderen sozialen Formen und Verhaltensweisen führen könnten. Die soziale Bedeutung dieses Studienbereichs könnte zunehmen, falls mehrere Untersuchungen zeigen würden, dass die Einstufungen der Ungleichheit soziale Auswirkungen haben, die zu den objektiven Ungleichheiten hinzugefügt werden müssen.

Schlagwörter : Ungleichheitsempfinden; Soziale Justiz; Internationaler Vergleich; Modernistische Perspektive; Wohlfahrtsstaaten. 